\title{
DAMA ARCHEOLOGII (WIELKO)POLSKIEJ
}

\section{ZAMIAST MOTTA}

„Trzeba mieć ogromne szczęście, aby od razu dokonać odkrycia tej miary!” powiedział prof. Gerard Labuda, nestor polskiej mediewistyki po odkryciu małego fragmentu fundamentów romańskich na Ostrowie Tumskim w Poznaniu. Pod koniec lata 1999 r. zszedł po drabinie do głębokiego wykopu, zdjął biały kapelusz i milcząco dotykał kamieni...

\section{NAJKRÓCEJ}

Hanna Kóčka-Krenz ukończyła studia na Uniwersytecie im. Adama Mickiewicza z zakresu historii sztuki i archeologii. Od 1973 r. była asystentem w Katedrze Archeologii UAM w Poznaniu, potem adiunktem, profesorem nadzwyczajnym UAM (1996) i profesorem nauk humanistycznych (2012). Zainteresowania naukowe Pani Profesor koncentrują się wokół zagadnień związanych z problematyką europejskiego średniowiecza, szczególnie złotnictwa strefy bałtyckiej (skandynawskiego i zachodniosłowiańskiego), początków średniowiecznego budownictwa obronnego w Wielkopolsce (tzw. siedziby na nasypach) oraz architektury monumentalnej. Honorowy Obywatel Miasta Poznania (2017) i Honorowy Prezes Poznańskiego Towarzystwa Przyjaciół Nauk (2017) - tyle sucha notka.

* Wydział Historyczny UAM, Instytut Archeologii, ul. Umultowska 89D, 61-614 Poznań, ands@amu.edu.pl. 


\section{A PRZECIEŻ...}

Bardzo bezpośrednia, ogólnie lubiana, życzliwa i pełna energii Pani Profesor to świetny dydaktyk i wykładowca akademicki, dziekan Wydziału Historycznego (2008-2012), dyrektor Instytutu Prahistorii, obecnie ponownie dyrektor Instytutu Archeologii UAM, prezeska Poznańskiego Towarzystwa Przyjaciół Nauk oraz członkini wielu prestiżowych gremiów naukowych w kraju i za granicą. Do tego kierownik badań wykopaliskowych w Wielkopolsce i romańskiego zespołu pałacowo-sakralnego na Ostrowie Tumskim w Poznaniu. „Dzięki Pani Profesor badaniom, odkryciom i publikacjom jeszcze bardziej zdajemy sobie sprawę z wyjątkowego miejsca Polski w europejskiej kulturze i historii" - podsumował prof. Andrzej Lesicki, rektor Uniwersytetu im. Adama Mickiewicza podczas uroczystości jubileuszowej z okazji 70. urodzin Uczonej, która „od zawsze” związana była z poznańską uczelnią, choć...

\section{NIE JEST POZNANIANKĄ}

Rodzice poznali się w Poznaniu. Wojciech Kóčka, po kursie językowym w Dalkach (pod Gnieznem), zaczął studia z archeologii i antropologii na Uniwersytecie Poznańskim. Zajęcia tego kierunku prowadzone były w gmachu przy ul. Matejki, w którym na I piętrze romanistykę studiowała Pani Adela. Mimo że mama pochodziła z Małopolski, ojciec z Łużyc, ich drogi skrzyżowały się w Poznaniu. Wybuch wojny i okupacja (W. Kóćkę ścigano za działalność konspiracyjną) były szczególnie trudnym czasem dla Kóćków. Po wyzwoleniu los rzucił ich do Wrocławia i tam... w domu rodzinnym, przy alei Piastów urodziła się przyszła archeolożka! Z perspektywy czasu wydaje się, że została „skazana na dłubanie w ziemi”. Ojciec zabierał swoją jedyną córkę na teren wykopalisk na wrocławskim Ostrowie Tumskim, potem - po zamieszkaniu w Grodzie Przemysła i podjęciu przez niego pracy w Instytucie Historii Kultury Materialnej, następnie Katedrze Archeologii Polski i Powszechnej UAM - na poznańskiej wyspie katedralnej. Towarzyszyła ojcu podczas wizytacji prac wykopaliskowych w Szczecinie, Gdańsku, na Ostrowie Lednickim i grodzisku w pomorskim Radaczu. Uczyła się w Prywatnym Żeńskim Liceum Sióstr Urszulanek Unii Rzymskiej (nauczycielką historii i wychowawczynią klasy była s. Aleksandra Witkowska, późniejsza profesor Katolickiego Uniwersytetu Lubelskiego), a - po zamknięciu szkoły przez władze - maturę zdała w VII Liceum Ogólnokształcącym im. Dąbrówki. Jeszcze przed maturą, w czasie wakacji, pracowała w wykopach na Ostrowie Lednickim i wtedy postanowiła: będę archeolożką! 

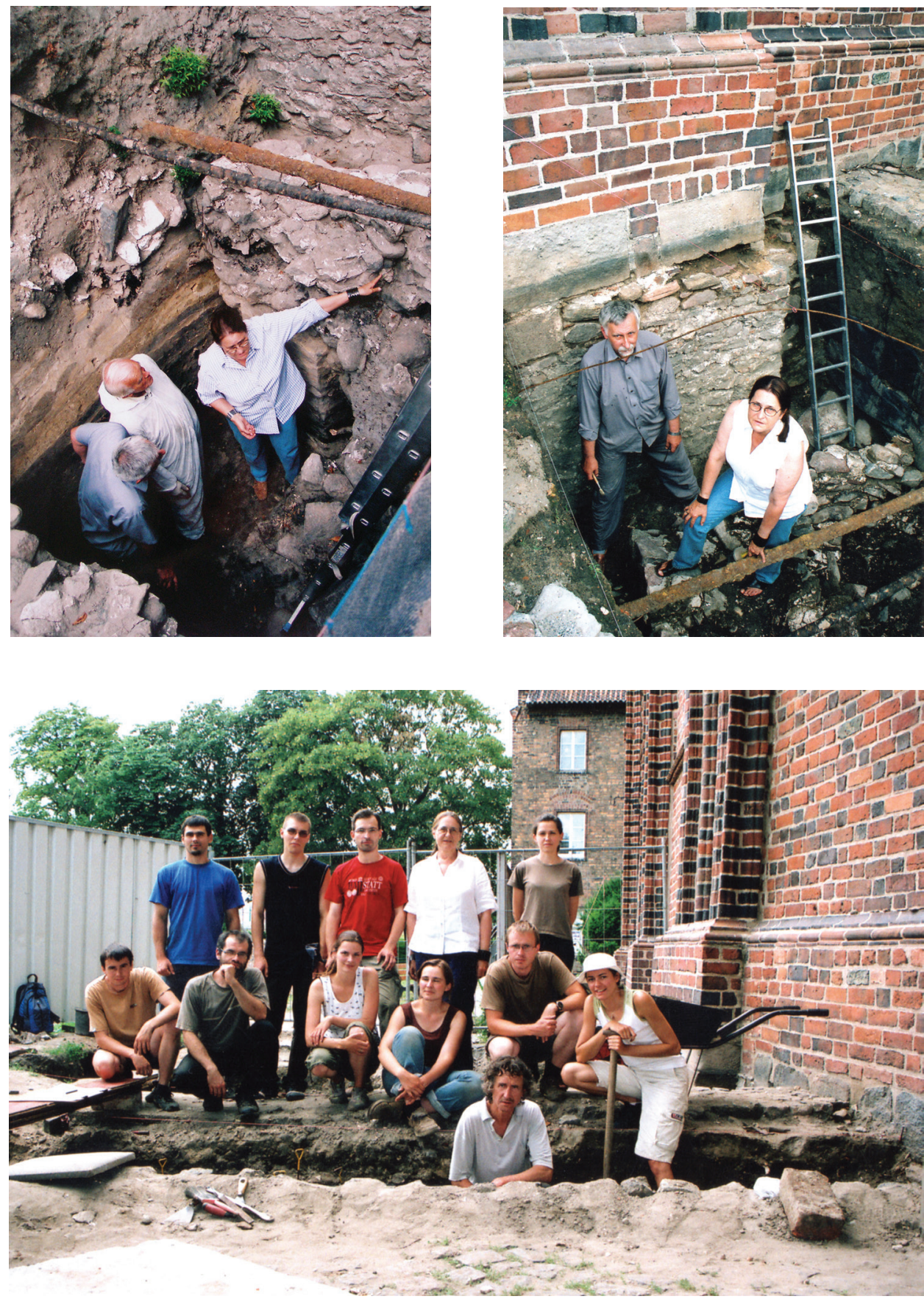

Fig. 1-3. Profesor Hanna Kóčka-Krenz podczas badań Ostrowa Tumskiego w Poznaniu w 2009 roku. Fot. O. Antowska-Gorączak 
Podobno tak zareagował prof. W. Kóčka i... Nabór na archeologię odbywał się co dwa lata. Za namową przyjaciółki, Hanki Łomnickiej, córki ówczesnego Wojewódzkiego Konserwatora Zabytków, wybrała architekturę wnętrz na poznańskiej Akademii Sztuk Pięknych. Nie została przyjęta! Egzaminy do ASP odbywały się wcześniej, poszła więc na historię sztuki (1964-1969), ale „nie odpuściła”. Po pierwszym roku równolegle studiowała archeologię, połączoną z etnografią (1965-1970).

\section{NAJWAŻNIEJSZE W ŻYCIU OSOBISTYM I ZAWODOWYM}

Wydarzyło się w Poznaniu. Z mężem Pawłem wychowali dwie córki (Agnieszkę i Martę), mają troje wnuków i wnuczkę. Pani Profesor umiejętnie dzieli obowiązki domowe $\mathrm{z}$ zawodowymi. Rodzinę $\mathrm{i}$ dom stawia na pierwszym miejscu (którą cementują niedzielne obiady, święta i inne uroczystości - wszystko sama przygotowuje!). Z Uniwersytetem im. Adama Mickiewicza związana jest ponad 50 lat. Praca naukowa zawsze przynosiła i daje Jej wiele satysfakcji. Tutaj przeszła przez wszystkie stopnie kariery naukowej. Aktywnie uczestniczy w życiu naukowym swojego UAM, innych szkół wyższych (wykłady zagraniczne) i gremiach pozauczelnianych (krajowych i zagranicznych).

\section{LIPCA 1999 R.}

Miała nosa (choć - po latach trzeba przyznać - ekipa nie była zadowolona, gdyż od 1 lipca 1999 r. miała jechać na badania grodziska nad jeziorem w Górze, koło Pobiedzisk)! Na głębokości 2,5 m ukazało się skupisko kamieni, ułożone - na odcinku 2 m - równolegle do zachodniej fasady gotyckiego kościoła pw. Najświętszej Maryi Panny (NMP). Pomiędzy kamieniami zalegały bryłki białej i różowej zaprawy gipsowej. W dzienniku naukowym odnotowano ...,,Wydaje się, że pośrednio mamy poziom romański”. - „Ostrożnie, bardzo ostrożnie doczyścić całość!” - padały dyspozycje. Stało się. Dokładnie w imieniny Pani Profesor - zagrzmiało! Prasa, radio, TV. „Tak, to był wyjątkowy prezent! - wspomina dziś. - Byłam głęboko przekonana, że odkopaliśmy fragment zaledwie 2-metrowego przedromańskiego fundamentu palatium książęcego z czasów Mieszka I. Środowisko archeologów i historyków przyjęło tę informację z lekkim niedowierzaniem, twierdząc, że się zagalopowałam. Właśnie wtedy przydała się intuicja i wiadomości z historii sztuki. Moja «diagnoza» częściowo opierała się na hipotezach ówczesnego dr. Witolda Hensla, który przypuszczał, że w miejscu, gdzie dzisiaj stoi kościół NMP, należy spodziewać się «pałacu Mieszki» - jak napisał w Kronice Miasta Poznania z 1938 roku. Zresztą sam próbował zidentyfikować to miejsce, miał mniej szczę- 
ścia. To odkrycie czekało na naszą łopatę!’. Potem odsłonięto relikty kaplicy i elementy jej wyposażenia.

Odkrycie zespołu pałacowo-sakralnego z czasów monarchii piastowskiej jest jej największym osiągnięciem i przygodą naukową, ale też - jak przyznawała - sporą niespodzianką. Wydawało się, że rezydencja Mieszka I będzie podobna do znanej z Ostrowa Lednickiego, jednak okazało się, iż jest inna, z wyjątkową formą architektoniczną i wyposażeniem. Wyniki kilkunastoletnich badań na Ostrowie Tumskim, prowadzonych pod kierunkiem Pani Profesor, przywróciły pamięć o roli Poznania w monarchii wczesnopiastowskiej.

\section{NIE TYLKO PAŁAC...}

Pani Profesor „dochowała się” prawie 200 magistrantów i wypromowała 8 doktorów (kilkunastu realizuje dysertacje). Opublikowała około 200 artykułów i kilka książek, w tym często cytowane Złotnictwo skandynawskie IX-XI wieku, Poznań 1983, Biżuteria północno-zachodniosłowiańska we wczesnym średniowieczu, Poznań 1993 (wyd. w 1994) i Na wyspie Ostrów, przy której dzisiaj jest Poznań... I On Ostrów Island, nearby which today's Poznań is located..., Poznań 2012. Ponadto jest redaktorem m.in. serii „Poznań we wczesnym średniowieczu”, t. 5-8, Poznań 2005-2013. Zasiada też w wielu redakcjach czasopism archeologicznych. Aktywnie działała w Fundacji Uniwersytetu im. Adama Mickiewicza przy organizacji prężnego Laboratorium C-14. Ma też swój wkład w utworzenie dwóch ważnych instytucji kulturalnych, tzn. Interaktywnego Centrum Historii Ostrowa Tumskiego w Poznaniu „Bramy Poznania” na poznańskiej Śródce i Rezerwatu Archeologicznego „Genius loci” na Ostrowie Tumskim. Sporo wniosła do obchodów 1050-lecia Chrztu Polski (wykłady, prezentacje, polemiki). O działaniach na rzecz promocji Poznania i Wielkopolski nie tylko w średniowieczu - wiadomo. Drzwi do gabinetu Pani Profesor są zawsze otwarte dla studentów i pracowników IA UAM! Niestrudzona, ciągle inspiruje, nie wzbrania się przed podejmowaniem niełatwych dyskusji naukowych $\mathrm{i}$ - co istotne - wysłuchuje, nie narzuca swego zdania.

NAUKA I...

Lubi media (nigdy nie odmawia wywiadów i rozmów), ceni dobrą książkę (nie kryminały, jak wybitni archeolodzy poznańscy: prof. Zofia Kurnatowska [1932-2013] i prof. Jan Żak [1923-1990]). Najlepiej wypoczywa w górach i na wykopaliskach; dobrze jeździ na nartach i dba o działkę. O Jej gościnności, umiejętnościach kulinarnych (szczególnie wypiekach i bożonarodzeniowej kutii) pisano nie raz. - „Pani Profesor to logo naszego poznańskiego Ostrowa Tumskie- 
go, ba, uniwersytetu" - twierdzi dawny mieszkaniec Psałterii, który z okna, przez lata, bacznie obserwował postępy prac badawczych przy kościele NMP.

\section{NAGRODY I WYRÓŻNIENIA}

Nie wszystkie działania zostały docenione, a o nagrodach i wyróżnieniach raczej dowiadywaliśmy się z mediów, nie od Pani Profesor. I tak, otrzymała m.in. Odznakę Honorową Miasta Poznania (1987), Złotą Odznakę Ministra Kultury i Dziedzictwa Narodowego „Za opiekę nad zabytkami” (2004), Medal Arcybiskupa Poznańskiego (2006), Nagrodę Złotego Hipolita oraz uznana została za Wybitną Osobistość Pracy Organicznej (2016). Oczywiście, była też wyróżniana za osiągnięcia naukowe: Złotym Krzyżem Zasługi Prezydenta RP (2011), Nagrodą im. Józefa Kostrzewskiego ((2014) i Nagrodą Ministra Szkolnictwa Wyższego za całokształt dorobku (2016). Bardzo wzruszyła się, odbierając dwa tomy dedykowanych Jej studiów pod wymownym tytułem „Gemma Gemmarum” (red. A. Różański, Poznań 2017, s. 1455), w których artykuły zamieściło ponad 80 autorów! Reprezentacyjna uniwersytecka Aula Lubrańskiego pękała w szwach.

NOWE WYZWANIA

„Praca naukowa jest ważną częścią mojego życia, a podejmowanie nowych wyzwań bywa szczególnie fascynujące. Ne pewno będą nimi badania nad pochodzeniem dynastii Piastowskiej, w ramach interdyscyplinarnego zespołu, w skład którego wchodzą antropolodzy, biochemicy i archeolodzy. Chcemy zbadać społeczeństwo i dynastię we wczesnym średniowieczu na podstawie analiz DNA. To «historia zapisana w kościach ludzkich». Może uda się rozstrzygnąć spór, czy Piastowie pochodzili z naszych elit, czy przybyli z zewnątrz? Instytut Archeologii UAM nadal znakomicie wpisuje się w badania nad przeszłością nie tylko Poznania” - mówi w jednym $\mathrm{z}$ wywiadów. I dodaje: „W rodzinie trwa ciągłość. Idę śladem ojca, a ścieżkę antropologiczną kontynuuje moja młodsza córka Marta i mam nadzieję, że tradycje pracy naukowej podejmie kolejne pokolenie...". 